\title{
PERJANJIAN GADAI BENDA ELEKTRONIK DI JAWA TENGAH
}

\author{
Mochammad Dja'is, Etty Susilowati, Suradi. Dessy Pintoko Nirmolo \\ Fakultas Hukum, Universitas Diponegoro \\ mochammaddjais73@gmail.com
}

\begin{abstract}
There is a deviation from the agreement using the sale and purchase agreement with the right to buy back. Buy back rights are lost if until the specified time the debtor (seller) does not buy back the object of the sale and purchase agreement, and the object of the sale and purchase agreement becomes the property of the buyer (creditor). This is called claim execution carried out in violation of pawn provisions. OJK must make POJK (Financial Services Authority Regulation which states null and void the concept of buying and selling with the right to buy back and oblige the buyer (the creditor / seller converts into a loan debt agreement with the guarantee of a movable object mortgage).
\end{abstract}

Keywords: claim execution; OJK; POJK

\begin{abstract}
Abstrak
Terdapat penyimpangan perjanjian gadai menggunakan perjanjian jual beli dengan hak membeli kembali. Hak membeli kembali hilang apabila sampai waktu yang ditentukan debitor (penjual) tidak membeli kembali obyek jual beli, dan obyek jual beli menjadi milik pembeli (kreditor). Hal ini disebut eksekusi mendaku yang dilakukan dengan melanggar ketentuan gadai. OJK harus membuat POJK (Peraturan Otoritas Jasa Keuangan yang menyatakan batal demi hukum konsep jual beli dengan hak membeli kembali dan mewajibkan pembeli (kreditor/penjual mengubah menjadi perjanjian utang piutang uang dengan jaminan gadai benda bergerak.
\end{abstract}

Kata kunci: eksekusi mendaku; OJK; POJK

\section{A. Pendahuluan \\ 1. Latar Belakang}

Dalam upaya meningkatkan inklusi keuangan bagi masyarakat menengah ke bawah dan usaha mikro, kecil dan menengah, pemerintah memandang perlu memperluas layanan jasa keuangan melalui penyelenggaraan usaha pergadaian.

Hukum positif tentang gadai masih plural. Hal ini belum memberi kepastian hukum, apabila dibiarkan dapat menimbulkan chaos.Untuk mencegah chaos diperlukan tindakan yang tegas yaitu pada Surat Bukti Gadai para pihak (pemberi dan penerima gadai) menentukan hukum positif yang digunakan pada perjanjian gadai tersebut. Selain itu, pada pra survai diketahui adanya pergadaian yang membuat perjanjian gadai dengan perjanjiaan jual beli dengan hak membeli kembali. Hak membeli kembali debitor (penjual) hapus (hilang) apabila tenggang waktu habis, debitor (penjual) tidak membeli kembali obyek jual beli. Selanjutnya obyek jual beli menjadi milik kraeditor (pembeli) Cara perolehan hak milik demikian dinamakan eksekusi mendaku yang melanggar hukum positif tentang perjanjian jaminan (gadai).

\section{Perumusan Permasalahan}

Berdasarkan uraian-uraian di atas, maka pemasalahan yang akan diteliti meliputi:

a. Hukum Positif apakah yang berlaku bagi perjanjian gadai?

b. Pluralisme ketentuan hukum positif tentang gadai, dapat menimbulkan 
ketidakpastian hukum, Bagaimana cara menjamin kepastian hukum?

c. Bagaimana praktek Perjanjian Gadai di Jawa Tengah?

d. Dalam hal Praktek perjanjian gadai di Jawa Tengah tidak sesuai dengan ketentuan hukum positif, langkah apakah yang harus diambil agar praktek perjanjian gadai sesuai dengan ketentuan hukum positif?

e. Dalam hal eksekusi obyek gadai tidak sesuai dengan ketentuan hukum positif, upaya apakah yang harus dilakukan agar eksekusi obyek gadai sesuai dengan ketentuan hukum positif?

\section{Tujuan Penelitian}

a. Untuk menentukan ketentuan gadai yang berlaku sebagai hukum positif. Dengan diketahuinya ketentuan gadai yang menjadi hukum positif, maka tercpailah kepastian hukum.

b. Untuk mengetahui Eksekusi atas benda elektronik oleh pegadaian profesi jika debitor wanprestasi. Selanjutnya dilakukan tindakan yang harus diambil pemerintah guna mengatasi praktek gadai profesi yang merugikan konsumen.

\section{Manfaat Penelitian}

Adapun manfaat yang diharapkan dapat diambil oleh penulis dari penelitian ini adalah sebagai berikut:

a. Manfaat Penelitian Secara Teoritis

b. Secara Praktis

\section{B. Tinjauan Pustaka}

\section{Istilah Dan Perumusan Gadai}

Istilah lembaga hak jaminan "Gadai" ini merupakan terjemahan kata pand atau vuitspand (bahasa Belanda) pledge atau pawn (bahasa Inggris) pfand atau faurt pfand (bahasa Jerman). Dalam hukum adat istilah gadai ini disebut cekelan.

Perumusan pengertian gadai diberikan dalam Pasal 1150 KUH Perdata sebagai berikut:

\footnotetext{
${ }^{1}$ Sri Soedewimasjchoen sofwan,Hukum Perdata:Hukum Benda,(Yogyakarta:Liberty,2008),hlm 97 dalam Rachmadi
}

Dari perumusan Pasal 1150 KUH Perdata tersebut dapat diketahui, bahwa:

a. Gadai merupakan suatu hak jaminan kebendaan atas kebendaan bergerak tertentu milik debitor atau seseorang lain atas nama debitor untuk dijadikan sebagai jaminan pelunasan utang tertentu.

b. Gadai memberikan hak didahulukan (voorrang,preferensi,droit de preference) kepada pemegang hak gadai terhadap kreditor-kreditor lainnya atas piutangnya.

c. Gadai memberikan kewenangan kepada kreditor pemegang gadai untuk mengambil pelunasan terlebih dahulu dari hasil penjualan melalui pelelangan umum atas barang-barang yang digadaikan setelah dikurangi biaya-biaya lelang dan biaya lainnya yang terkait dengan proses lelang.dan biaya penyelamatan benda. ${ }^{1}$

\section{Sifat-Sifat Gadai}

Ternyata dari defisi gadai belum terungkap semua sifat-sifat gadai. Untuk mengetahui sifat-sifat gadai dapat ditemukan dalam ketentuan-ketentuan lain dari $\mathrm{KUH}$ Perdata.

Adapun sifat-sifat dari gadai adalah:

a. Gadai adalah hak kebendaan

Pemegang gadai mempunyai hak revindikasi dari Pasal 1977 Ayat (2) KUH Perdata apabila barang gadai hilang atau dicuri. Hak kebendaan dari hak gadai bukanlah hak untuk menikmati suatu benda seperti eigendom, hak bezit, hak pakai dan sebagainya. Memang benda gadai harus diserahkan kepada kreditor tetapi tidak untuk dinikmati, melainkan untuk menjamin terlunasi piutangnya dengan mengambil

(Jsman,Hukum Kebendaan,(Jakarta:Sinar Grafika,2008),hlm 
penggantian dari benda tersebut guna mambayar piutangnya. ${ }^{2}$

b. Hak Gadai bersifat Accesoir

Hak gadai merupakan hak ikutan atau accessoir yang ada dan tidak tergantung atau accessoir, yang ada dan tidaknya tergantung dari ada dan tidaknya piutang yang merupakan perjanjian pokoknya. dengan demikian perjanjian hak gadai akan hapus jika perjanjian pokoknya hapus.

c. Hak gadai tidak dapat dibagibagi

Karena hak gadai tidak dapat dibagibagi maka dengan dibayarnya sebagian utang tidak akan membebaskan sebagian dari benda gadai. Hak gadai tetap membebani benda gadai secara keseluruhan.

d. Hak gadai adalah hak yang didahulukan

Hak gadai adalah hak yang didahulukan ini dapat diketahui dari ketentuan Pasal 1133 dan 1150 KUH Perdata.

e. Benda yang menjadi obyek gadai adalah benda bergerak, baik yang bertubuh maupun tidak bertubuh.

Dalam Pasal 1140 KUH Perdata disebutkan bahwa gadai diperoleh kreditor atas suatu benda bergerak yang diserahkan keapadanya oleh seorang debitor atau orang lain atas nama debitor.

f. Hak gadai adalah hak yang kuat dan mudah penyitaannya.

Dalam Pasal 1134 Ayat (2) KUH Perdata dinyatakan bahwa:

Hak gadai dan hipotik lebih diutamakan daripada privilege, kecuali jika undang-undang menentukan sebaliknya.

\section{Objek Gadai}

Ada dua faktor yang membedakan jaminan gadai dibanding jaminan lainnya misalnya Hak Tanggungan atau Hipotek: Pertaina, yaitu faktor benda objek jaminan utang; dan kedua berupa penguasaan atas benda objek jaminan utang tersebut.

Seperti yang telah disebutkan, ketika gadai dibuat maka barang objek gadai harus diserahkan ke dalam kekuasaan pihak kreditor, ketentuan ini berlaku mutlak.

\section{Subjek Hukum Hak Gadai}

Dan ketentuan dalam Pasal 1150 KUH Perdata, yang antara lain kata-kata nya menyatakan "gadai adalah suatu hak yang diperoleh seorang berpiutang atas suatu barang bergerak, yang diserahkan kepadanya oleh seorang berutang atau oleh orang lain atas namanya".

\section{Hak dan Kewajiban Pemegang Gadai.}

a. Hak-hak pemegang gadai adalah sebagai berikut:

1) Hak untuk mengeksekusi parat (Pasal 11155 KUH Perdata)

2) Hak untuk menahan benda gadai (hak retentie) [Pasal 1159 Ayat (1) KUH Perdata]

3) Hak Kompensasi (Pasal 1159 ayat (2) KUH Perdata)

4) Hak untuk mendapatkan ganti rugi atas biaya yang telah dikeluarkan untuk menyelamatkan benda gadai. (Pasal 1157 ayat (2) KUH Perdata)

5) Hak menjual dalam kepailitan debitor(Pasal 56 peraturan kepailitan).

6) Hak Preferensi

7) Atas izin hakim tetap menguasai benda gadai (Pasal 1156 Ayat (1) KUH Perdata).

8) Hak menjual benda gadai dengan perantara Hakim

9) Hak untuk memerima bunga gadai (Pasal 1158 KUH Perdata)

10) Hak untuk menagih piutang gadai

11) Hak untuk menahan benda gadai (hak retentie)

12) Hak Kompensasi

13) Hak untuk mendapatkan ganti rugi atas biaya yang telah dikeluarkan untuk menyelamatkan benda gadai (Pasal 1157 ayat (2) KUH Perdata).

\footnotetext{
2 Purwahid patrik dan Kashadi,Hukum Jaminan,(Semarang:Badan Penerbit Universitas Diponegoro,.2009),hlm 23
} 
14) Hak menjual dalam kepailitan debitor

15) Hak Preferensi

16) Atas izin hakim tetap menguasai benda gadai (Pasal

17) 1156 Ayat (1) KUH Perdata).

18) Hak menjual benda gadai dengan perantara Hakim

19) Hak untuk memerima bunga gadai (Pasal 1158 KUH Perdata)

20) Hak untuk menagih piutang gadai

b. Kewajiban pemegang gadai adalah sebagai berilut:

1) Kewajiban memberitahukan kepada pemberi gadai jika benda gadai akan dijual.

2) Kewajiban memelihara benda gadai (Pasal 1157 Ayat (1) dan Pasal 1159 ayat (1) KUH Perdata)

Adapun kewajiban pemegang gadai adalah sebagai berikut:

1) Kewajiban memberitahukan kepada pemberi gadai jika benda gadai akan dijual.

2) Kewajiban memelihara benda gadai Kewajiban memelihara benda gadai ini dapat disimpulkan dan bunyi Pasal 1157 Ayat (1) dan Pasal 1159 ayat (1) KUH Perdata. Begitu pula pemegang gadai tidak boleh menyalahgunakan benda gadai (Pasal 1159 ayat (1) KUH Perdata.

3) Kewajiban untuk memberikan perhitungan antara hasil penjualan benda gadai dengan besarnya kewajiban pemberi gadai membayar.

4) Kewajiban mengembalikan benda gadai (Pasal 1159 ayat (1) KUH Perdata)

5) Kewajiban untuk memperhitungkan hasil penagihan bunga piutang gadai dengan besarnya bunga piutangnya kepada debitor.

6) Kewajiban untuk mengembalikan sisa hasil penagihan piutang gadai kepada pemberi gadai.

\section{Hak Dan Kewajiban Pemberi Gadai}

a. Hak-hak pemberi gadai:

1) Hak untuk menerima sisa hasil pendapatan penjualan benda gadai setelah dikurangi dengan piutang pokok, bunga dan biaya dan pemegang gadai.

2) Hak untuk menerima penggantian benda gadai apabila benda gadai telah hilang dan kekuasaan si pemegang gadai.

b. Kewajiban-kewajiban pemberi gadai:

1) Demi keselamatan benda gadai dari bencana alam Iforce majeur di dalam praktek sering kali pemberi gadai diwajibkan untuk mengasuransikan benda gadai. Kewajiban ini memang efisien untuk kredit dalam jumlah besar.

2) Apabila yang digadaikan adalah piutang, maka selama piutang itu digadaikan, pemberi gadai tidak boleh melakukan penagihan atau menerima pembayaran dan debitornya (debitor piutang gadai).

\section{Hapusnya Gadai}

1. Karena hapusnya perikatan pokok Hak gadai adalah hak accesoir, dengan hapusnya perikatan pokok membawa serta hapusnya hak gadai.

2. Karena benda gadai keluar dari kekuasaan pemegang gadai.

\section{Metode Penelitian}

\section{Penelitian Dan Lokasi Penelitian}

Sesuai dengan judul penelitian "Gadai Benda Elektronik di Jawa Tengah" maka penelitian dilakukan di daerah yang banyak dilakukan penggadaian benda elektronik (Laptop, Handphone, Tablet dll) banyak dimiliki dan dibutuhkan oleh generasi muda khususnya mahasiswa. Sehubungan dengan hal tersebut maka terdapat korelasi yang erat antara jumlah mahasiswa dengan perjanjian gadai benda elektronik. Berdasar pertimbangan tersebut maka pemilihan lokasi penelitian didasarkan pada jumlah perguruan tinggi. Jawa Tengah terdiri dai 35 kabupaten/Kota (daftar kabupaten/kota se Jawa Tengah TERLAMPIR dengan berbagai perguruan tinggi negeri maupun swasta daftar perguruan tinggi se Jawa Tengah TERLAMPIR) 


\section{Metode Pengumpulan Data}

Dalam penelitian ini, dibedakan antara istilah Bahan Hukum dengan Data. Bahan Hukum terdiri dari Norma-norma hukum tentang perjanjian gadai benda elektronik yang terdiri dari bahan hukum primer, bahan hukum sekunder dan bahan hukum tersier. Sedangkan data adalah praktik hukum perjanjian gadai elektronik yang dilakukan oleh masyarakat. Terdiri dari data primer dan data sekunder.

\section{Bahan Hukum}

1. Bahan hukum Primer terdiri dari:

a. Peraturan Otoritas Jasa Keuangan Nomor 31IPOJK.05/2016 tentang Usaha Pegadaian.

b. Kitab Undang-undang Hukum Perdata.

c. Peraturan Pemerintah Nomor 56 Tabun 1960 tentang Penetapan Luas Tanah Pertanian Presiden Republik Indonesia

d. Staatsblad tahun 1928 nomor 81

e. Peraturan Pemerintah Nomor 51 Tahun 2011 tentang perubahan Perubahan Bentuk Badan Hukum Perusahaan Umum (Perum) Pegadaian Menjadi Perusahaan Perseroan (Persero).

f. Hukum gadai atau agunan dalam islam (Rahn)

2. Bahan hukum sekunder
a. Hasil karya ilmiah para sarjana yang relevan dengan materi penelitian
b. Hasil-hasil penelitian yang relevan dengan materi penelitian

3. Bahan hukum tersier
a. Bibiliografi yang relevan dengan materi penelitian.
b. Kamus/ ensiklopedia yang relevan dengan materi penelitian.

\section{Data}

\section{Data Primer}

a. Data-data yang diperoleh dari hasil observasi di Lapangan kepada sejumlah pegadaian elektronik.

b. Praktik yang dilakukan antara pemberi gadai dan pemegang gadai pada pegadaian elektronik.

\section{Data Sekunder}

Terdiri dari praktik hukum di pengadilan melalui Yurisprudensi Mahkamah Agung.

Dalam menentukan sampel penelitian, penulis menempuh langkah-langkah sebagai berikut:

a. Menentukan lokasi penelitian

b. Lokasi dalam penelitian ini adalah Kota Semarang dan Kota Surakarta.

c. Menentukan sampel dan responden.

Penentuan sampel dilakukan dengan menggunakan teknik purposive sampling, yaitu menunjuk secara langsung sampel yang akan diteliti sesuai dengan tujuan yang hendak dicapai karena alasan yang terdapat pada populasi.

\section{Metode Analisis Dan Penyajian Data}

Setelah semua data yang diperlukan itu sudah dipilih dan dikumpulkan yang representative maka tindakan selanjutnya adalah menganalisisnya.

Untuk memudahkan penggarapan penulisan hasil penelitian, maka dilakukan kegiatan-kegiatan yang menyangkut pengolahan dan penyajian data yang merupakan suatu metode, sebagai berikut:

a. Editing, yaitu memeriksa atau meneliti data-data yang telah diperoleh untuk menjamin apakah sudah dapat dipertanggungjawabkan dan sesuai dengan kenyataan ataukah belum.

b. Klasifikasi, yaitu mengidasifikasikan data-data yang telah diperoleh kemudian menggabung-gabungkannya ke dalam golongan yang sejenis.

c. Aplikasi, yaitu menerapkan data-data yang telah dikiasifikasikan dan digolong-golongkan tersebut ke dalam bab-bab serta sub-sub bab dari laporan hasil penelitlan ini.

Khusus untuk peraturan perundangundangan, langkah-langkah yang dilakukan sebagai berikut:

a. Memilih pasal-pasal yang berisi normanorma hukum yang mengatur mengenai praktik gadai elektronik

b. Menyusun sistematika dari pasal-pasal tersebut sehingga menghasilkan kiasifikasi tertentu. 
c. Menganalisa pasal-pasal tersebut dengan mempergunakan asas-asas hukum yang ada.

d. Menyusun konstruksi yuridis untuk mengatasi permasalahan yang bersangkutan.

Daftar Kabupaten/Kota di Jawa Tengah

Daftar Perguruan Tinggi Negeri Dan Swasta

Di Jawa Tengah

I. Daftar Perguruan Tinggi Negeri (PTN) di Jawa Tengah

II. Daftar Perguruan Tinggi Swasta (PTS) di Jawa Tengah

\section{Metode Pendekatan}

Penulisan hukum memerlukan suatu penelitian yang mana dengan penelitian tersebut diharapkan akan diperoleh data yang akurat sebagai pemecahan permasalahan atau jawaban atas pertanyaan-pertanyaan tertentu yang diajukan..

\section{Metode Pengumpulan Data}

Dalam penelitian ini, dibedakan antara istilah Bahan Hukum dengan Data. Bahan Hukum terdiri dari Norma-norma hukum tentang perjanjian gadai benda elektronik yang terdiri dari bahan hukum primer, bahan hukum sekunder dan bahan hukum tersier.

\section{Hasil Penelitian dan Pembahasan}

1. Hukum Positif Yang Berlaku Bagi Perjanjian Gadai

e. Kitab Undang-Undang Hukum Perdata

Manusia sebagai makhluk social menurut kodratnya selalu membutuhkan orang lain untuk hidup bermasyarakat. Dalam hidup bermasyarakat perlu dijaga tata tertib/ Tertib masyaraakat tercapai apabila selisih komponen dalam masyarakat tersebut tertib, temasuk bidang hukum. Tertib hukum tercapai apabila terdapat penegakan hukum oleh aparat penegak hukum melalui prosedur yang benar (prosedur yang diatur dalam masyarakat yang bersangkutan).

Ketentuan Pasal II Aturan Peralihan bearguna untuk mencegah terjadinya kekosongan hukum. Ketentuan yang serupa dengan Pasal II Aturan Peralihan, diatur dalam Pasal 192 Konstitusi RIS, Pasal 102 UUD S1950. f. Prinsip syariah

Adalah ketentuan Hukum Islam berdasarkan fatwa dan/ atau pernyataan kesesuaian syariah dari Dewan Syariah Nasional Majelis Ulama Indonesia.

g. Staatsblad 1928 Nomor 81

tentang Pandhuis Reglement dan Peraturan Pemerintah nomor 51 Tahun 2011 tentang Perubahan Bentuk Badan Hukum Perusahaan Umum (Perum) Pegadaian menjadi Perusahaan Perseroan (Persero). Ketentuan ini berlaku bagi Pegadaian Profesi Pemerintah yang semboyannya terkenal dengan "mengatasi masalah tanpa masalah".

h. Peraturan atau Ketentuan Otoritas Jasa Keuangan (POJK)

OJK adalah lembaga yang mengawasi dan membina Perusahaan Pergadaian, sehubungan dengan itu maka, OJK diberi wewenang untuk mengeluarkan peraturan atau ketentuanketentuan yang harus ditaati oleh perusahaan pergadaian baik dalam segi kelembagaan maupun dalam aktivitas usahanya.

\section{Cara Menjamin Kepastian Hukum} Positif

Berdasarkan uraian tersebut diketahui bahwa dalam pinjam-meminjam uang dengan jaminan gadai terdapat beberapa ketentuan hukum positif (Kitab UndangUndang Hukum Perdata, Prinsip Syariah, Staatsblad 1928 Nomor 81, Peraturan atau Ketentuan Otoritas Jasa Keuangan (POJK) ). Hal itu berarti bahwa dibidang pinjam meminjam uang dengan jaminan gadai telah terjadi Pluralisme Hukum.

\section{Praktek Perjanjian Gadai Di Jawa Tengah}

Pada umumnya praktek perjanjian gadai benda elektronik di Jawa Tengah sesuai dengan Ketentuan Hukum Positif, namun ada perusahaan pergadaian yang membuat perjanjian gadai berupa perjanjian jual beli dengan hak membeli kembali. 


\section{Langkah Yang Harus Diambil Dalam Hal Praktek Perjanjian Gadai Tidak Sesuai Dengan Ketentuan Hukum Positif}

Sebagai Pengawas dan Pembina usaha pergadaian OJK (Otoritas Jasa Keuangan) membuat POJK (Peraturan Otoritas Jasa Keuangan) yang isinya melarang perusahaan pergadaian membuat perjanjian jual beli dengan hak membeli kembali untuk perjanjian gadai dan menyatakan batal demi hukum konsep perjanjian jual beli dengan hak membeli kembali bagi perjanjian gadai serta memerintahkan kreditor (penjual) untuk mengganti konsep perjanjian jual beli dengan hak membeli kembali dengan perjanjian utang piutang uang dengan jaminan gadai benda bergerak.

\section{Ketidaksesuaian Eksekusi Dengan} Ketentuan Hukum Positif Bersumber Pada Perjanjian Gadai Yang Dirumuskan Sebagai Perjanjian Jual Beli Dengan Hak Membeli Kembali.

Bertitik tolak pada hal tersebut, maka langkah yang harus diambil agar praktek eksekusi sesuai dengan ketentuan hukum positif adalah OJK (Otoritas Jasa Keuangan) membuat POJK (Peraturan Otoritas Jasa Keuangan) yang isinya melarang perusahaan pergadaian membuat perjanjian jual beli dengan hak membeli kembali untuk perjanjian gadai dan menyatakan batal demi hukum konsep perjanjian jual beli dengan hak membeli kembali bagi perjanjian gadai serta memerintahkan kreditor (penjual) untuk mengganti konsep perjanjian jual beli dengan hak membeli kembali dengan perjanjian utang piutang uang dengan jaminan gadai benda bergerak.

\section{E. Simpulan dan Saran}

1. Simpulan

a. Praktik gadai benda elektronik di Jawa Tengah ada perusahaan yang membuat perjanjian gadai tidak perjanjian jaminan utang, melainkan perjanjian jual beli dengan hak membeli kembali.

b. Pluralisme dalam perjanjian gadai dapat menimbulkan keaatidakpastian hukum, bahkan menimbulkan keadaan chaos. c. Terjadi penyimpangan prosedur eksekusi obyek gadai benda elektronik di Jawa Tengah, yaitu dengan eksekusi mendaku.

d. Dalam pengawasan dan pembinaan terhadap perusahaan pergadaian Otoritas Jasa Keuangan harus tetap menjaga agar perjanjian gadai memuat ketentuan yang sesuai dengan ketentuan hukum positif.

e. OJK (Otoritas Jasa Keuangan) membuat POJK (Peraturan Otoritas Jasa Keuangan) yang isinya melarang perusahaan pergadaian membuat perjanjian jual beli dengan hak membeli kembali untuk perjanjian gadai dan menyatakan batal demi hukum konsep perjanjian jual beli dengan hak membeli kembali bagi perjanjian gadai serta memerintahkan kreditor (penjual) untuk mengganti konsep perjanjian jual beli dengan hak membeli kembali dengan perjanjian utang piutang uang dengan jaminan gadai benda bergerak.

2. Saran

Disarankan kepada Otoritas Jasa Keuangan (OJK) didalam melakukan pengawasan dan pembinaan usaha pergadaian dengan mengeluarkan peraturan yang melarang dan menyatakan batal demi hukum semua ketentuan atau konsep perjanjian yang dibuat oleh perusahaan pergadaian yang tidak sesuai dengan hukum positif tentang gadai.

\section{DAFTAR PUSTAKA}

\section{BUKU-BUKU :}

Achmad Busro, Hukum Perikatan berdasar

Buku II $\quad K U H$
Perdata,(Yogyakarta:Pohon
Cahaya,2011)

H.F.A Vollmar, Pengantar Studi Hukum Perdata, (Jakarta:CV Rajawali,1983)

Kartini Muljadi dan Gunawan Widjaja, Hak Istimewa, Gadai dan Hipotek,(jakarta:Prenanda Media, 2005)

Ko Tjay Sing, Hukum Benda,( Semarang: tanpapenerbit,tanpa tahun) 
Mariam Darus Badrulzaman, Bab-bab tentang Credietverband, Gadai \& Fiducia,(Bandung:Alumni,1981)

Mohammad Saleh dan Lilik Mulyadi, Bunga Rampai Hukum Acara Perdata Indonesia,(Bandung:Alumni,2012)

Munir Fuady,hukum jaminan hutang,(Jakarta:Erlangga,2013)

P.S. Atiyah, An Introduction to the Law of Contract, $5^{\text {th }}$ edition,(Oxford:Clarendon Press, 1955)

Purwahid Patrik dan kashadi, Hukum Jaminan, ( Semarang: Badan Penerbit Universitas Diponegoro,2009)

RA Van der Poll, Hak-hak Jaminan, compedium Hukum Belanda,(Jakarta:Intermasa,1977)

Rachmadi Usman,Hukum Jaminan Keperdataan,(Jakarta: Sinar Grafika,2008)

Rochmat Soemitro, Peraturan dan Instruksi Lelang,(Bandung:PT.Fresco,1987)
Roni Hanitjo Soemitro,Metodologi Peneitian Hukum dan jurimetri. (Jakarta : Ghalia Indonesia, 1990)

Salim, Perkembangan Hukum Jaminan di Indonesia,(Jakarta:Raja Grafino,2005)

Sarwono, Hukum Acara Perdata Teori dan Praktik,(Jakarta:Sinar Grafika,2011)

Sri Soederwi masjchoen sofwan,Hukum Perdata Hukum Benda (Yogyakarta:Liberty,1981)

Yahya Harahap, Ruang LingkupPermasalahan Eksekusi Bidang Perdata,(Jakarta:Sinar Grafika,2005)

\section{UNDANG-UNDANG}

Kitab Undang-Undang Hukum Perdata

Pertauran Otoritas Jasa Keuangan Nomor 31/ POJK.05/2016 tentang Usaha Pergadaian. 